\title{
Mercury Contamination of the Belgian Avifauna 1970-1981
}

\author{
K. Delbeke,* C. Joiris* \& G. Decadt $\dagger$ \\ *Laboratorium voor Ecotoxicologie, \\ $\dagger$ Laboratorium voor Analytische Scheikunde, \\ Vrije Universiteit Brussel, B-1050 Brussels, Belgium
}

\begin{abstract}
$A B S T R A C T$
Two hundred birds found dead in Belgium between 1970 and 1981, and belonging to 30 species, were analysed for total mercury contamination. The contamination of aquatic birds ranged between 0.11 and $35 \mu \mathrm{gg}^{-1}$ wet weight. For terrestrial birds, the extreme values were: not detectable and $14 \mu \mathrm{g} \mathrm{g}^{-1}$. In both cases, differences in diet can explain the differences in contamination. The order of diets associated with increasing mercury contamination for aquatic birds was invertebrates, zooplankton and garbage, and fish; and for terrestrial birds this consisted of plants, invertebrates, mammals and birds. For raptors and owls, this effect of diet includes geographical variations within species. A higher mercury contamination level in the winter and early spring was noted for two species of owls. For aquatic birds, the contamination of liver was higher than that of kidney, with ratios varying between 1.2 and 2.5. For terrestrial birds, the ratio was closer to 1. A few determinations were also made for muscle and heart, giving respectively 0.25 and 0.6 of the liver contamination. Among the birds analysed for their liver contamination, $15 \%$ showed levels higher than $3 \mu \mathrm{g} \mathrm{g}^{-1}$ and could have been affected in their reproduction; $3 \%$ had levels higher than $10 \mu \mathrm{g} \mathrm{g}^{-1}$, and could have died from mercury poisoning; and $6 \%$ showed an abnormally high liver:kidney ratio, which could reflect an acute intoxication.

There exists a striking parallelism between the levels of mercury and of organochlorine residues (DDT) in birds of prey, suggesting the existence of common ecotoxicological mechanisms.
\end{abstract}

205

Environ. Pollut. Ser. B. 0143-148X/84/\$03.00 (C) Elsevier Applied Science Publishers Ltd, England, 1984. Printed in Great Britain 


\section{INTRODUCTION}

In 1953, the catastrophic Minamata disease clearly showed the potentia danger of mercury accumulation. Due to its high biological stability and its high absorption capacity ( 80 to $100 \%$ : Aberg et al., 1969), mercury, and more especially its methyl form, is often found at high concentrations at the end of food webs, for instance in Japan (Swedish Expert Group, 1971), Iraq (Bakir et al, 1973), or in Scandinavia, where it was utilised as 1971), Iraq (Bakir et al., 1973), or in Sc

Now that the use of or Now that the use of organochlorine pesicides is strongly limited in Western countries, heavy metals, and among them mercury, probably represent the main threat to the environment and to the health of the human population. This is why we decided to investigate the contamination of Belgian wildlife.

Birds found dead in Belgium were used as study material because enough information is available concerning their feeding habits and population dynamics. Among them, raptors are of special interest when studying the contamination of an ecosystem by stable compounds for two reasons.

1. Because of their broad territorium and long lifespan they integrate small variations in contamination level.

2. The available information concerning residues levels of other stable compounds-organochlorine pesticides and PCBspermits a comparison of ecotoxicological mechanisms.

METHODS

\section{Sampling}

Two-hundred-and-one birds found dead in Belgium between 1970 and 1981 and belonging to 30 species were analysed. Liver, kidney and in some cases muscle and heart were kept deep-frozen $\left(-20^{\circ} \mathrm{C}\right)$ until needect. The rins a

\section{Analytical procedure}

Six different procedures to determine the total mercury concentrations in biological samples were compared in the Laboratory for Analytical
Chemistry (Dehairs et al., 1982); two methods gave similar results, one of which was applied in routine analyses. It consisted of the mineralisation of samples with a $\mathrm{H}_{2} \mathrm{SO}_{4} / \mathrm{HNO}_{3}$ mixture in the presence of $\mathrm{V}_{2} \mathrm{O}_{5}$ as of samples with $\mathrm{H}_{2} \mathrm{SO}_{4} / \mathrm{HNO}_{3}$ mixture in the prolyst followed by $\mathrm{KMnO}_{4}$ digestion, both under reflux. The excess of $\mathrm{KMnO}_{4}$ is reduced with $\mathrm{NH}_{4} \mathrm{OCl}$ and the mercury to $\mathrm{Hg}^{\circ}$ with $\mathrm{NaBH}_{4}$ The mercury concentration is measured through cold vapour atomic absorption (Coleman MAS 50). The results are expressed as $\mu \mathrm{g} \mathrm{Hg} \mathrm{g}^{-1}$ wet weight. In some samples, the dry weight was also determined: thi provided three to four times higher contaminations, but did not seem to influence the comparison between species or between tissues.

\section{Statistics}

Because mercury levels do not always show a normal distribution pattern, median levels were used, as we considered that they give a better evaluation of the contamination of the population than do mean values. The significance of the observed differences was evaluated by a nonThe significance of the observed differences was evaluated by a nonparametric test (Median test: Siegel, 1956). The mean levels, as well as
their standard deviation, are, however, listed in the tables, for the different their standard deviatio
tissues of each species.

\section{Comparison of the mercury contamination of various species}

All aquatic birds were contaminated by mercury, but at very variable levels, ranging from $0 \cdot 11 \mu \mathrm{g} \mathrm{g}^{-1}$ in a kingfisher Alcedo atthis to more than $35 \mu \mathrm{g} \mathrm{g}^{-1}$ in a cormorant Phalacrocorax carbo. These differences between $35 \mu \mathrm{g} \mathrm{g}^{-1}$ in a cormorant Phalacrocorax carbo. These differences between
species could be explained by differences in diet: birds feeding mainly on species could be explained by differences in diet: birds feeding mainly on zooplankton and garbage (significance, $P<0.05$ ), while those having a zooplankton and garbage (significance, $P<0.05)$, while those having a
diet of fish and invertebrates showed the lowest mercury levels $(P<0.02)$ diet of fish

A broad range of mercury levels was also noted in the terrestrial birds: from not detectable to $14 \mu \mathrm{g} \mathrm{g}^{-1}$. Differences in diet were associated with different mercury levels. The order of diets associated with increasing mercury contamination was: plants, insects, mammals, birds. All these differences were significant $(P<0 \cdot 10)$ when enough samples were analysed (Table 2). 


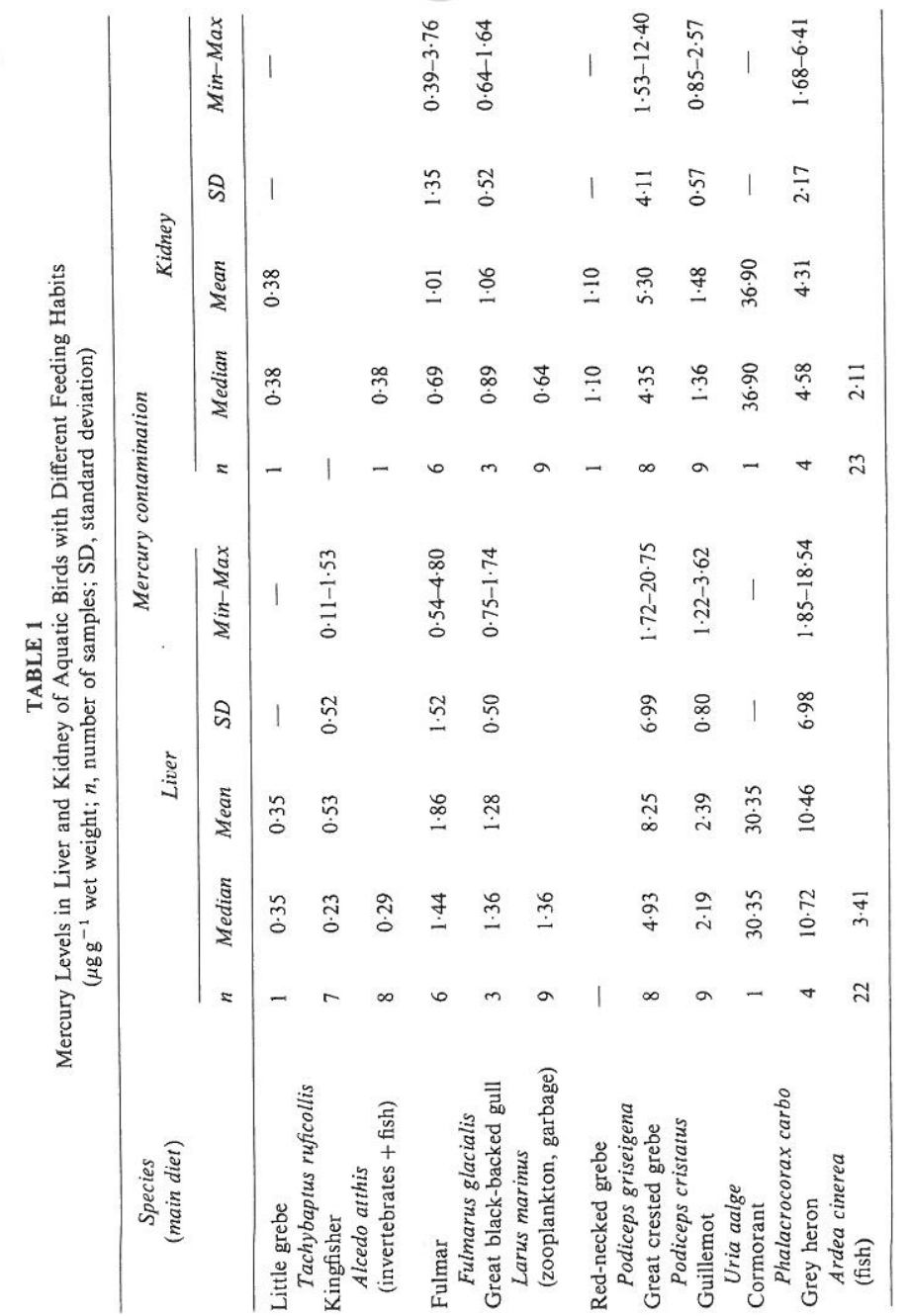

Geographical variation within terrestrial systems

Two zones have been defined in Belgium, north and south of the rivers Sambre, Meuse and Vesdre, in parallel with previous studies on organochlorine contamination (Joiris \& Delbeke, 1981).

The long-eared owl Asio otus and the barn owl Tyto alba from the The lon nor he regut from the the owls having more passerin in their diet in the nainly of forests zone than in the southern zone which consist me meadows. It was interesting to note that in the buzzard Buteo buteo, significant difference in contamination (Table 3).

\section{Distribution pattern of mercury within various tissues}

For the different species of aquatic birds, the mercury levels in kidney and liver were closely related this was noted each time the number of samples was big enough to allow the comparison. The contamination of kidney was lower than that of liver: the ratio of mercury in liver to kidney varied between 1.2 and 2.5 (Table 4, Fig. 1). A positive correlation between liver and kidney mercury levels, with a higher level in liver, was noted in birds sacrificed in previous studies (Finley \& Stendell, 1978; Hutton, 1981). A higher liver than kidney mercury contamination has been noted for the fulmar but no correlation between liver and kidney was, however, established (Osborn et al., 1979).

For the raptors the levels in liver and kidney were also positively For (he rat 5 . Fig 2) related (Table 5, Fig. 2). The ratio be 1.1 with the exception of the barn owl, in which a higher ratio was found. With the barn owl there was also a much lower correlation coefficient, due to the presence of six birds with high liver contamination, which possibly had been exposed to acute intoxication.

As far as muscle and heart samples were concerned, only a few determinations were done. The results are summarised in Appendix The relation between muscle $(M)$ and liver $(L)$ contamination was

$$
M=0.24 L+0.08 \quad(r=0.61, n=22)
$$

and/or heart $(H)$, the equation was

$$
H=0.57 L+0.06 \quad(r=0.90, n=12)
$$




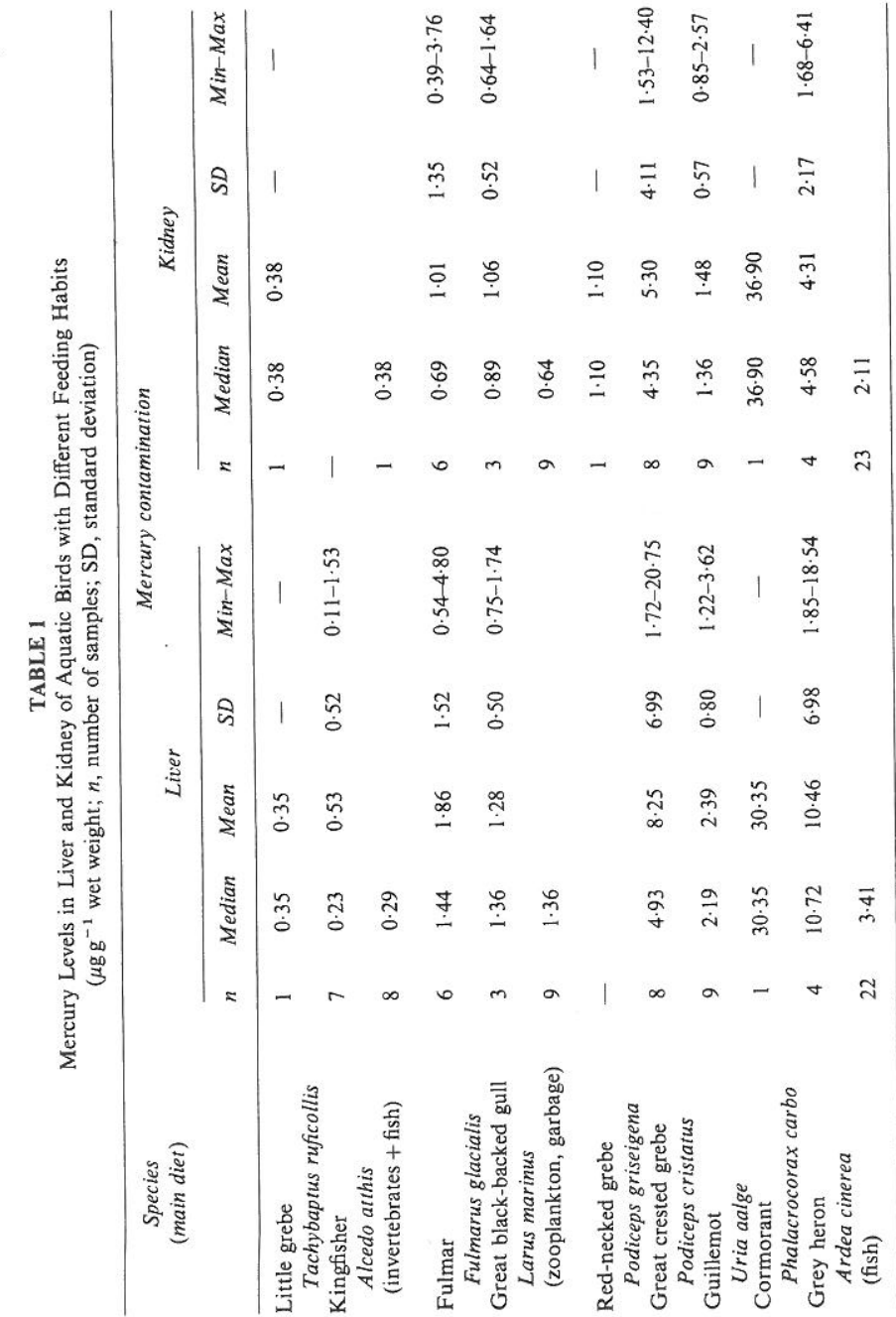

Geographical variation within terrestrial systems

Two zones have been defined in Belgium, north and south of the rivers Sambre, Meuse and Vesdre, in paraliel with previous studies on organochlorine contamination (Joiris \& Delbeke, 1981).

The long-eared owl Asio otus and the barn owl Tyto alba from the Ther from the southern region. This was again explained by dietary differences: from the southern region. This w in their diet in the northern (agricultural) the owls having more passerises in their diet in the northenn (agrioultura) zone than in the southern zone which consists mainly of forests an meadows. It was interesting to note that in the buzzard Buteo buteo, where the diet consists mainly of rodents in both significant difference in contamination (Table 3).

\section{Distribution pattern of mercury within various tissues}

For the different species of aquatic birds, the mercury levels in kidney and liver were closely related: this was noted each time the number of sample was big enough to allow the comparison. The contamination of kidney was lower than that of liver: the ratio of mercury in liver to kidney varied between 1.2 and 2.5 (Table 4, Fig. 1). A positive correlation between liver and kidney mercury levels, with a higher level in liver, was noted in bird sacrificed in previous studies (Finley \& Stendell, 1978; Hutton, 1981). A higher liver than kidney mercury contamination has been noted for the fulmar but no correlation between liver and kidney was, however established (Osborn et al., 1979).

For the raptors, the levels in liver and kidney were also positively For the raptors, the related (Table 5, Fig. 2). The ratio bet and 11 with the exception of the ever, closer to 1 , varying between 0.8 and 1 With the barnowl there was barn owl, in which a higher ratio was found. With the barn owl there was also a much lower correlation coefficient, due to the presence or six birds with high liver contamination, which possibly had been exposed to acute intoxication.

As far as muscle and heart samples were concerned, only a few determinations were done. The results are summarised in Appendix 1. The relation between muscle $(M)$ and liver $(L)$ contamination was

$$
M=0.24 L+0.08 \quad(r=0.61, n=22)
$$

and/or heart $(H)$, the equation was

$$
H=0.57 L+0.06 \quad(r=0.90, n=12)
$$


TABLE 2

Mercury Levels in Liver and Kidney of Terrestrial Birds with Different Feeding Habits ( $\mu \mathrm{g} \mathrm{g}^{-1}$ wet weight; $n$, number of samples; $\mathrm{SD}$, standard deviation)

\begin{tabular}{|c|c|c|c|c|c|c|c|c|c|c|}
\hline \multirow{3}{*}{$\begin{array}{c}\text { Species } \\
\text { (Main diet) }\end{array}$} & \multicolumn{10}{|c|}{ Mercury contamination } \\
\hline & & & & & & & & & & \\
\hline & $n$ & Median & Mean & $S D$ & Min-Max & $n$ & Median & Mean & $S D$ & Min-Max \\
\hline $\begin{array}{l}\text { Jay } \\
\quad \text { Garrulus glandarius }\end{array}$ & - & & & & & 1 & 0.05 & 0.05 & - & - \\
\hline $\begin{array}{l}\text { Magpie } \\
\text { Pica pica }\end{array}$ & - & & & & & 2 & $0 \cdot 11$ & 0.11 & - & $0.04-0 \cdot 18$ \\
\hline $\begin{array}{l}\text { Jackdaw } \\
\quad \text { Corcus monedula }\end{array}$ & - & & & & & 1 & $0 \cdot 14$ & $0 \cdot 14$ & - & - \\
\hline $\begin{array}{l}\text { Carion crow } \\
\text { Corius corone }\end{array}$ & - & & & & & 4 & $0 \cdot 15$ & $0 \cdot 26$ & $0 \cdot 26$ & $0.09-0.64$ \\
\hline $\begin{array}{l}\text { Raven } \\
\text { Corrus corax }\end{array}$ & - & & & & & 3 & 0.05 & 0.05 & 0.01 & $0.04-0.06$ \\
\hline $\begin{array}{l}\text { Collard turtle dove } \\
\text { Streptopelia decaocto } \\
\text { (omnivorous, mainly plants) }\end{array}$ & - & & & & & $\begin{array}{c}1 \\
12\end{array}$ & $\begin{array}{l}0.10 \\
0.09\end{array}$ & $0 \cdot 10$ & - & - \\
\hline $\begin{array}{l}\text { Honey buzzard } \\
\text { Pernis apirorus }\end{array}$ & 1 & 0.08 & 0.08 & - & - & 1 & 0.03 & 0.03 & - & - \\
\hline $\begin{array}{l}\text { Roller } \\
\text { Coracias garrulus } \\
\text { (insects) }\end{array}$ & - & 0.08 & & & & $\begin{array}{l}1 \\
2\end{array}$ & $\begin{array}{l}0.35 \\
0.19\end{array}$ & $0 \cdot 35$ & - & - \\
\hline $\begin{array}{l}\text { Little owl } \\
\quad \text { Athene noctua } \\
\text { (mammals + invertebrates) }\end{array}$ & $\begin{array}{l}24 \\
24\end{array}$ & $\begin{array}{l}0 \cdot 28 \\
0 \cdot 28\end{array}$ & 0.82 & $2 \cdot 11$ & $0.01-10.58$ & $\begin{array}{l}19 \\
19\end{array}$ & $\begin{array}{l}0.31 \\
0.31\end{array}$ & 1.05 & $3 \cdot 17$ & $0 \cdot 05-14 \cdot 10$ \\
\hline
\end{tabular}

\begin{tabular}{|c|c|c|c|c|c|c|c|c|c|c|}
\hline $\begin{array}{l}\text { Kite } \\
\quad \text { Milcus miltus }\end{array}$ & 1 & $0 \cdot 18$ & $0 \cdot 18$ & - & - & 1 & 0.17 & 0.17 & - & - \\
\hline $\begin{array}{l}\text { Buzzard } \\
\text { Buteo buteo }\end{array}$ & 24 & 0.59 & $1 \cdot 10$ & 1.67 & $0.02-4.38$ & 15 & 0.35 & 0.66 & 0.66 & $0.05-2.34$ \\
\hline $\begin{array}{l}\text { Marsh harrier } \\
\text { Circus aeruginosus }\end{array}$ & 1 & $0 \cdot 17$ & 0.17 & - & - & 1 & $0 \cdot 10$ & $0 \cdot 10$ & - & - \\
\hline $\begin{array}{l}\text { Kestrel } \\
\quad \text { Falco tinnunculus }\end{array}$ & 15 & $0 \cdot 34$ & 0.69 & 0.73 & $0.05-1.33$ & 11 & 0.45 & 0.53 & $0 \cdot 40$ & $0 \cdot 11-1 \cdot 26$ \\
\hline $\begin{array}{l}\text { Barn owl } \\
\text { Tyto alba }\end{array}$ & 28 & 0.86 & 1.35 & 1.23 & $0 \cdot 07-4 \cdot 31$ & 23 & 0.89 & 1.09 & 0.92 & $0-3.45$ \\
\hline $\begin{array}{l}\text { Eagle owl } \\
\text { Bubo bubo }\end{array}$ & 1 & 1.67 & 1.67 & - & - & 1 & 0.92 & 0.92 & - & - \\
\hline $\begin{array}{l}\text { Long-eared owl } \\
\text { Asio otus }\end{array}$ & 27 & 0.53 & 0.97 & $1 \cdot 20$ & $0-5.82$ & 10 & 0.26 & 0.47 & 0.64 & $0-2 \cdot 14$ \\
\hline $\begin{array}{l}\text { Short-eared owl } \\
\text { Asio flammeus }\end{array}$ & 1 & 0.70 & 0.70 & - & - & - & & & & \\
\hline $\begin{array}{l}\text { Tawny owl } \\
\text { Strix aluco }\end{array}$ & 8 & $0 \cdot 36$ & 0.65 & 0.62 & $0.12-1.92$ & 4 & 0.76 & 0.85 & 0.42 & $0.46-1.44$ \\
\hline (mammals) & 106 & 0.57 & & & & 66 & 0.54 & & & \\
\hline $\begin{array}{l}\text { Goshawk } \\
\quad \text { Accipiter gentilis }\end{array}$ & 2 & 5.04 & 5.04 & - & $0.40-10.68$ & 1 & 0.34 & 0.34 & - & - \\
\hline $\begin{array}{l}\text { Sparrowhawk } \\
\text { Accipiter nisus }\end{array}$ & 14 & $2 \cdot 84$ & $3 \cdot 15$ & $2 \cdot 31$ & $0 \cdot 35-8 \cdot 14$ & 14 & 3.08 & $3 \cdot 48$ & 2.46 & $0.44-7.88$ \\
\hline $\begin{array}{l}\text { Merlin } \\
\quad \text { Falco columbarius }\end{array}$ & 2 & 0.66 & 0.66 & 0.22 & $0.50-0.81$ & 2 & 0.46 & 0.46 & 0.09 & $0 \cdot 50-0.81$ \\
\hline (birds) & 18 & $2 \cdot 84$ & & & & 17 & 2.94 & & & \\
\hline
\end{tabular}


TABLE 3

Mercury Levels in Liver and Kidney of Raptors from Two Regions in Belgium ( $\mu \mathrm{g} \mathrm{g}^{-1}$ wet weight; $n$, number of samples)

\begin{tabular}{|c|c|c|c|c|c|c|c|c|}
\hline \multirow[t]{3}{*}{ Species } & \multirow[t]{3}{*}{ Region } & \multirow{3}{*}{$\begin{array}{c}\text { Diet }^{a} \\
(\% \text { of birds) }\end{array}$} & \multirow{2}{*}{\multicolumn{6}{|c|}{ Mercury level }} \\
\hline & & & & & & & & \\
\hline & & & Median & $(n)$ & Min-Max & Median & (n) & Min-Max \\
\hline Buzzard & $\mathrm{N}$ & 5 & 0.60 & (12) & $0 \cdot 02-4.38$ & 0.31 & (7) & $0.05-1 \cdot 17$ \\
\hline Buteo buteo & $\mathrm{S}$ & 5 & 0.46 & (4) & $0 \cdot 14-7.69$ & $0 \cdot 24$ & (2) & $0.14-0.33$ \\
\hline Long-eared owl & $\mathrm{N}$ & 25 & $1 \cdot 14$ & (14) & $0 \cdot 22-5 \cdot 82$ & 1.54 & (2) & $0 \cdot 93-2 \cdot 14$ \\
\hline Asio otus & $\mathrm{S}$ & 3 & $0 \cdot 30$ & (5) & $0 \cdot 27-1 \cdot 35$ & $0 \cdot 10$ & (2) & $0-0.19$ \\
\hline $\mathrm{P}-\mathrm{n}$ owl & $\mathrm{N}$ & 10 & $1 \cdot 26$ & (16) & $0 \cdot 07-4 \cdot 31$ & $1 \cdot 01$ & (14) & $0.08-3.40$ \\
\hline yto alba & $\mathrm{S}$ & 0 & $0 \cdot 28$ & (3) & $0.14-1.63$ & 0.77 & (2) & $0.70-0.84$ \\
\hline
\end{tabular}

$\mathrm{N}$, Northern zone; S, southern zone (see text).

${ }^{a}$ Uttendörfer (1952); E. Delmée (personal communication); Van der Straeten (1974); Godin (1975); Leurquin (1975).

TABLE 4

ation Between the Mercury Levels ( $\mu \mathrm{gg}^{-1}$ wet weight) in Kidney $(K)$ and Liver $(L)$ of Aquatic Birds. The Data Concern Only Determinations in Liver and Kidney of the Same Bird

( $n$, Number of samples; $r$, correlation coefficient; * $P<0.01 ; * * P<0.001$ )

\begin{tabular}{|c|c|c|c|c|}
\hline \multirow[t]{2}{*}{ Species } & \multirow[t]{2}{*}{$n$} & \multirow[t]{2}{*}{ Regression } & \multirow[t]{2}{*}{$r$} & Ratio \\
\hline & & & & Katlo \\
\hline Grey heron Ardea cinerea & 4 & $K=0.30 L+1 \cdot 17$ & 0.97 & $2 \cdot 44$ \\
\hline Guillemot Uria aalge & 9 & $K=0.63 L-0.02$ & $0 \cdot 88^{*}$ & $1 \cdot 61$ \\
\hline Great-crested grebe Podiceps cristatus & 7 & $K=0.83 L-0.03$ & $0 \cdot 97^{* *}$ & $1 \cdot 22$ \\
\hline Fulmar Fulmarus glacialis & 6 & $K=0.81 L-0.41$ & $0.94^{*}$ & 1.85 \\
\hline Great black-backed gull Larus marinus & 3 & $K=0.96 L-0.17$ & 0.91 & $1 \cdot 20$ \\
\hline
\end{tabular}

TABLE 5

Relation Between the Mercury Levels ( $\mu \mathrm{gg}^{-1}$ wet weight) in Liver $(L)$ and Kidney $(K)$ of Raptors ( $n$, Number of samples; $r$, correlation coefficient; ${ }^{*} P<0.01 ; * * P<0.001$ )

\begin{tabular}{|c|c|c|c|c|}
\hline Species & $n$ & Regression & $r$ & Ratio $\frac{\text { Liver }}{\text { Kidney }}$ \\
\hline Kestrel Falco tinnunculus & 11 & $K=0.75 L+0.11$ & $0 \cdot 88^{* *}$ & 1.07 \\
\hline Buzzard Buteo buteo & 13 & $K=1.03 L+0.06$ & $0 \cdot 93^{* *}$ & $0 \cdot 88$ \\
\hline Sparrowhawk Accipiter nisus & 13 & $K=0.90 L+0.70$ & $0 \cdot 85^{* *}$ & $0 \cdot 89$ \\
\hline Little owl Athene noctua & 18 & $K=1.33 L-0.05$ & $0.99 * *$ & 0.79 \\
\hline Tawny owl Strix aluco & 4 & $K=0.78 L+0.33$ & $0 \cdot 77$ & $0 \cdot 77$ \\
\hline Long-eared owl Asio otus & 10 & $K=1.08 L-0.10$ & $0 \cdot 94 * *$ & $1 \cdot 12$ \\
\hline
\end{tabular}



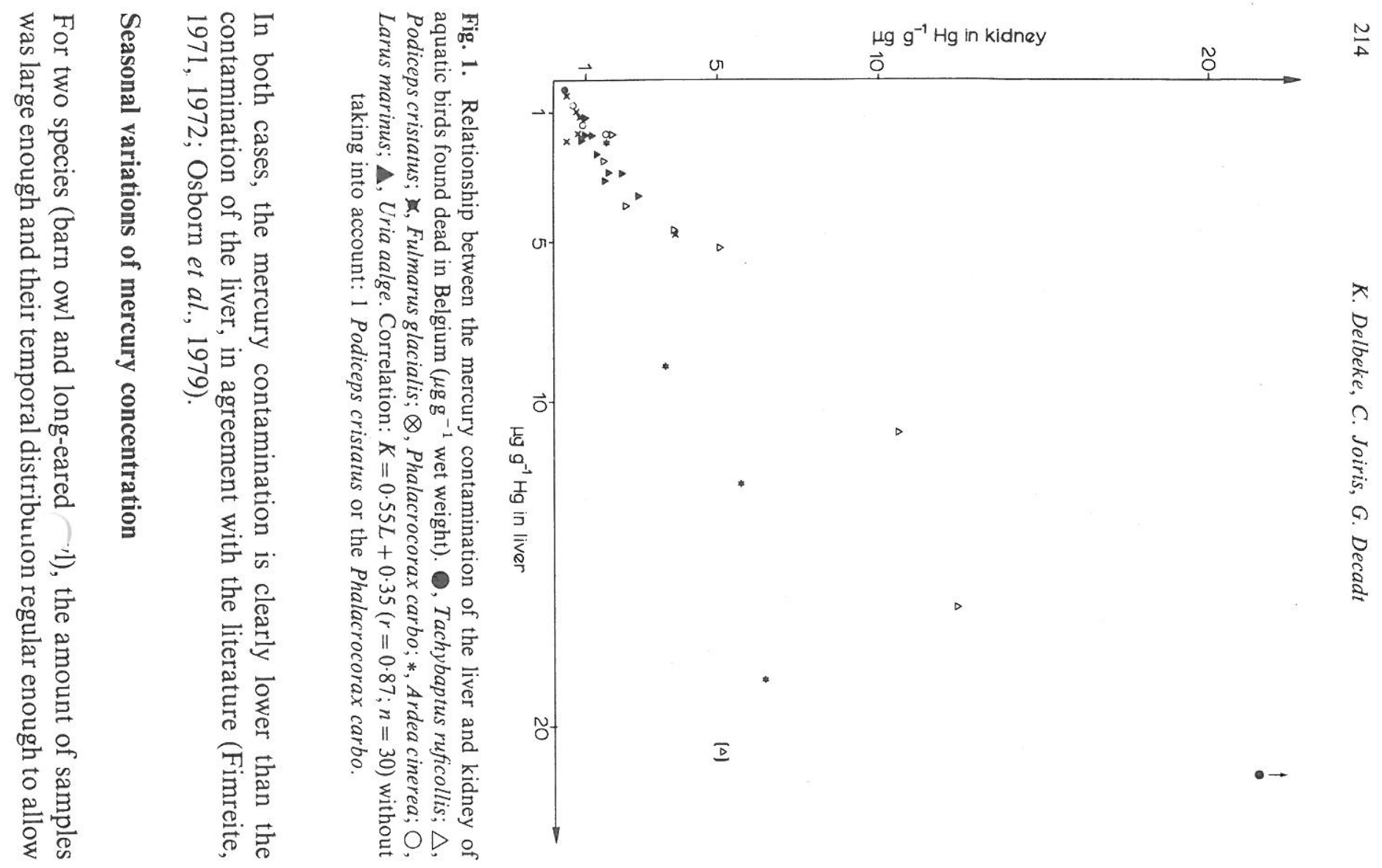

TABLE 6

Mercury Levels in Liver and Kidney of Owls-Temporal Variations ( $\mu \mathrm{g} \mathrm{g}^{-1}$ wet weight; $n$, number of samples)

\begin{tabular}{|c|c|c|c|c|c|c|c|}
\hline \multirow[t]{2}{*}{ Species } & \multirow[t]{2}{*}{$\begin{array}{c}\text { Period } \\
\text { (months) }\end{array}$} & \multicolumn{6}{|c|}{ Mercury level } \\
\hline & & Median & $(n)$ & Min-Max & Median & $(n)$ & Min-Max \\
\hline \multirow[t]{12}{*}{ Long-eared owl Asio otus } & I & 0.45 & $(6)$ & $0-1 \cdot 10$ & $0 \cdot 19$ & (3) & $0-0.93$ \\
\hline & II & $2 \cdot 04$ & (2) & $1 \cdot 35-2 \cdot 74$ & & & \\
\hline & III & $1 \cdot 46$ & (7) & $0.69-2.01$ & $0 \cdot 32$ & (1) & \\
\hline & IV & $1 \cdot 80$ & (1) & & $2 \cdot 14$ & (1) & \\
\hline & $\mathrm{V}$ & - & & & - & & \\
\hline & VI & - & & & - & & \\
\hline & VII & $0 \cdot 42$ & $(2)$ & $0.30-0.52$ & - & & \\
\hline & VIII & $0 \cdot 52$ & (1) & & $0 \cdot 19$ & (1) & \\
\hline & IX & $0 \cdot 57$ & (1) & & - & & \\
\hline & $X$ & - & & & - & & \\
\hline & XI & $1 \cdot 76$ & (1) & & - & & \\
\hline & XII & 0.69 & (1) & & 一 & & \\
\hline \multirow[t]{9}{*}{ Barn owl Tyto alba } & I & $3 \cdot 10$ & (4) & $1 \cdot 03-3 \cdot 54$ & $1 \cdot 21$ & $(5)$ & $0.64-3.45$ \\
\hline & II & $1 \cdot 35$ & (3) & $0 \cdot 55-2 \cdot 92$ & $0 \cdot 96$ & (4) & $0.89-3.07$ \\
\hline & III & - & & & - & & \\
\hline & IV & $0 \cdot 38$ & (1) & & 0.62 & (1) & \\
\hline & V & $0 \cdot 14$ & (1) & & - & & \\
\hline & VI & 0.77 & (3) & $0 \cdot 28-0.95$ & - & & \\
\hline & VII & 1.61 & (1) & & - & & \\
\hline & VIII & - & & & - & & \\
\hline & IX & 0.32 & (2) & $0 \cdot 21-0.43$ & $0 \cdot 20$ & (1) & \\
\hline
\end{tabular}




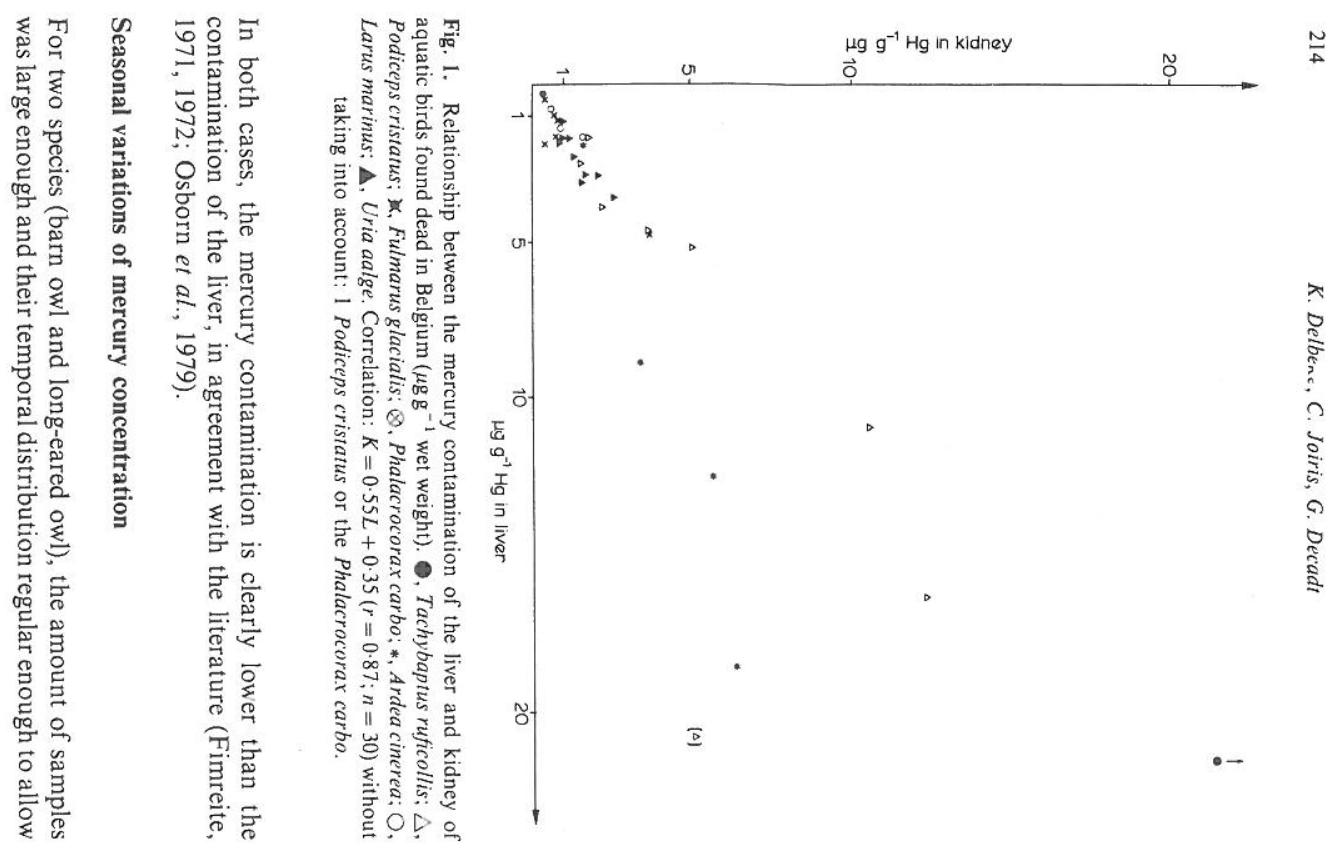

TABLE 6

Mercury Levels in Liver and Kidney of Owls-Temporal Variations ( $\mu \mathrm{g} \mathrm{g}^{-1}$ wet weight; $n$, number of samples)

\begin{tabular}{|c|c|c|c|c|c|c|c|}
\hline \multirow[t]{2}{*}{ Species } & \multirow[t]{2}{*}{$\begin{array}{c}\text { Period } \\
\text { (months) }\end{array}$} & \multicolumn{6}{|c|}{ Mercury level } \\
\hline & & Median & $(n)$ & Min-Max & Median & $(n)$ & Min-Max \\
\hline \multirow[t]{11}{*}{ Long-eared owl Asio otus } & $\begin{array}{r}\text { I } \\
\text { II }\end{array}$ & $\begin{array}{l}0.45 \\
2.04\end{array}$ & $\begin{array}{l}(6) \\
(2)\end{array}$ & $\begin{array}{r}0-1 \cdot 10 \\
1.35-2.74\end{array}$ & 0.19 & (3) & $0-0.93$ \\
\hline & III & 1.46 & (7) & $0.69-2.01$ & 0.32 & (1) & \\
\hline & IV & 1.80 & (1) & & $2 \cdot 14$ & (1) & \\
\hline & V & - & & & - & & \\
\hline & VI & - & & & - & & \\
\hline & VII & 0.42 & (2) & $0.30-0.52$ & - & & \\
\hline & VIII & 0.52 & (1) & & $0 \cdot 19$ & (1) & \\
\hline & IX & 0.57 & (1) & & - & & \\
\hline & $\mathrm{x}$ & - & & & - & & \\
\hline & XI & 1.76 & (1) & & - & & \\
\hline & XII & 0.69 & (1) & & - & & \\
\hline \multirow[t]{12}{*}{ Barn owl Tyto alba } & I & $3 \cdot 10$ & (4) & $1 \cdot 03-3 \cdot 54$ & $1 \cdot 21$ & (5) & $0.64-3.45$ \\
\hline & II & $1 \cdot 35$ & (3) & $0.55-2.92$ & 0.96 & (4) & $0.89-3.07$ \\
\hline & III & - & & & - & & \\
\hline & IV & $0 \cdot 38$ & (1) & & 0.62 & (1) & \\
\hline & V & $0 \cdot 14$ & (1) & & - & & \\
\hline & VI & 0.77 & (3) & $0 \cdot 28-0.95$ & - & & \\
\hline & VII & 1.61 & (1) & & - & & \\
\hline & VIII & - & & & - & & \\
\hline & IX & 0.32 & (2) & $0.21-0.43$ & $0 \cdot 20$ & (1) & \\
\hline & $\mathrm{X}$ & 0.77 & (3) & $0.29-2.25$ & 0.49 & (2) & $0.43-0.56$ \\
\hline & XI & 0.17 & (2) & $0.07-0.28$ & $0 \cdot 10$ & (2) & $0.08-0.11$ \\
\hline & XII & $3 \cdot 10$ & (2) & $1.89-4.31$ & 1.92 & (3) & $0.84-1.92$ \\
\hline
\end{tabular}




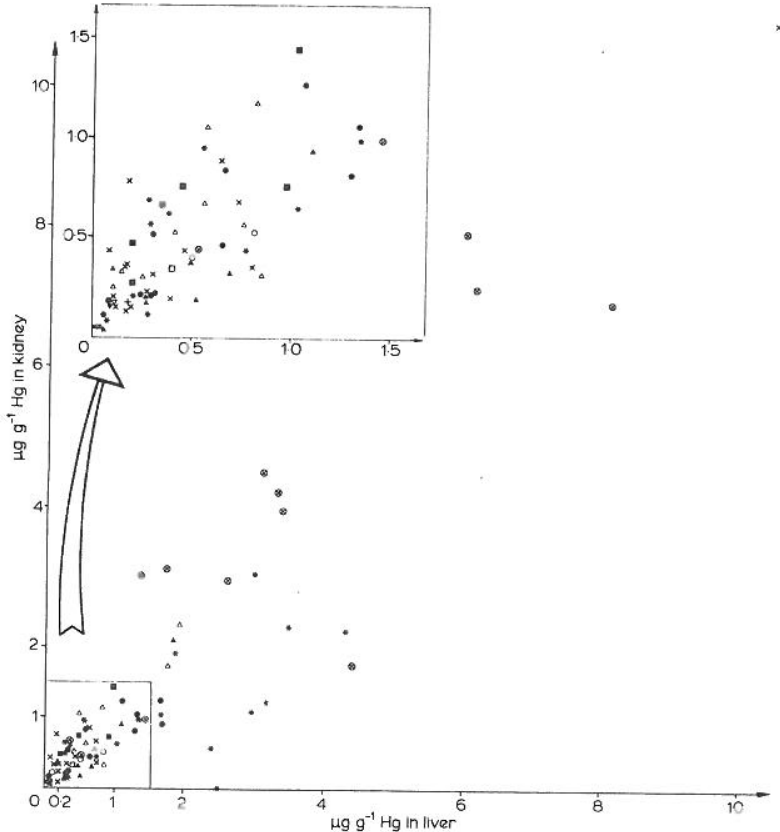

Fig. 2. Relationship between the mercury contamination of the liver and kidney of Fig. 2. Relationship between the mercury contamination of the
raptors found dead in Belgium $\left(\mu \mathrm{g} \mathrm{g}^{-1}\right.$ wet weight). The lower part of the graph, up to raptors found dead in Belgium $\left(\mu \mathrm{g} \mathrm{g}^{-1}\right.$ wet weight). The lower part of the graph, up to
$1.5 \mu \mathrm{gg}^{-1}$, has been enlarged for clarity. $\nabla$, Pernis apivorus;,+ Millus miltus: $\square$. , Falco tinnunculus: * Tyto alba: \& Bubo bubo; $A$, A sio olus: noctua; $\mathbf{\square}$. Strix aluco. Correlation: $K=1 \cdot 1 L-0.04(r=0.96 ; n=76)$.

the investigation of seasonal variation in mercury levels. For the longeared owl, the levels detected in the liver were higher from February to April (median: $1.51 \mu \mathrm{g} \mathrm{g}^{-1}, n=10$ ) than for the rest of the year $\left(0.52 \mu \mathrm{g} \mathrm{g}^{-1}, n=12\right)$ (Table 6). For the barn owl, the levels were higher from December to February (liver: $2.92 \mu \mathrm{g} \mathrm{g}^{-1}, n=9$; kidney: $1.16 \mu \mathrm{g} \mathrm{g}^{-1}, n=12$ ) than for the rest of the year (liver: $0.38 \mu \mathrm{g} \mathrm{g}^{-1}, n=13$ kidney: $\left.0.31 \mu \mathrm{g} \mathrm{g}^{-1}, n=6\right)$. These differences are highly significant $(P<$ $0.005)$

\section{DISCUSSION}

For ethical reasons, we decided not to shoot birds, but to use birds found dead. This makes it difficult to extrapolate between our results and the levels of mercury that would be found in the living population. However, $50 \%$ to $60 \%$ of raptors found dead had died through trauma (car accident, shot, etc.) (Glue, 1971; Weir, 1971; Newton et al., 1982), and several authors have taken the pollutant levels in such birds to be reasonably representative of those in the living population (see Cooke $e t$ al. (1982) for a discussion). This, together with the finding that mercury concentration in trauma birds and birds from other groups differ littlewith the exception of the barn owl (Cooke et al., 1982) - makes it unlikely that our sampling method has unduly biased our results.

The observed contamination levels of the different species have the The obser con cos same order of magnitude as those observed in other countries (Fimreite $c$ al., 1971, Fimreite, 1972, Greichus et al, 1973, Veluzet al., 1976; Juillar Thecon, Furness \& Hutton, 1979; Hutton, 1981; Cooke et al., 1982). The contamination of he various species is clearly diet-dependent. Fo aquatic birds, Fimreite (1971) has shown that the mercury levels are related to the percentage of animals in the food. Hutton (1981) noted differences in the mercury content of three species of aquatic birds with different feeding habits. In this study, a more detailed knowledge of the feeding habits of a large variety of species gave a better understanding of the contamination levels: birds feeding on fish have twice as high a mercury level as species feeding on fish, zooplankton and garbage. These latter bird species are in turn four times more contaminated than birds feeding on fish and insects. Using a $0.2 \mu^{-1} \mathrm{~g}^{-1}$ value for marine fish in our zone (Blaton, 1973) a concentration factor of 10 can be calculated from fish to bics. Such a value is in good agreent with published data fish to birds. Such a value is in go77) A higher mith published dat (Fimreite etal, 1971; Holzinger, 1977). A higher mercury contamination of raptor0) feeding on birds than on mammals, noted earlier (Fimreite et al., 1970), is also clear in our results. Not only is this difference quantitative one to be expressed as a correlation between the contamination of the raptors and the amount of birds in their diet, but is also valid within species (owls): differences in feeding habits between tw geographical regions within Belgium lead to differences in contamination. The relation between the median mercury level in the liver $(L)$ of raptors belonging to different species and regions (taking into accoun only median values consisting of at least 4 samples) and the percentage o birds in their diet $(B)$ was 


$$
L=0.026 B+0.35 \quad(r=0.94, n=9)
$$

and for kidney $(K)$, the equation was

$$
K=0.029 B+0.30 \quad(r=0.97, n=7)
$$

It is worth noting that the same conclusions have been drawn earlier in studies on the contamination of raptors by DDT (Joiris \& Delbeke, 1981). The DDT levels in different tissues and eggs, as well as eggshell thinning, were completely explained by the diet characteristics of the raptors, including their annual and geographical variations. The contamination of including their annuland geographical the preyitems sh. Fin that passerines are ind small mammals. Finally, laboratory experiments (Joinis et al., details to be published later) showed a higher elimination rate in mammals than in birds, which explains the differences in contamination.

The similarity in contamination patterns of mercury and DDT suggests the existence of similar ecotoxicological mechanisms for both types of stable compounds.

A higher contamination was detected for two species of owls, during the winter and early spring. A similar trend has already been noted for the barn owl and kestrel (Bell et al., 1978; Cooke et al., 1982) and might be associated with different mechanisms such as a seasonal variation in the diet, more birds being consumed in the winter period, or with a seasonal varion found high meris during the found higher mercury levels in the starling Sth uns bularis during the winter. Finally, a redistribution of mercury within the body could be due to the loss of fat during the winter and/or during the moulting periods. It is difficult to give a toxicological interpretation of our data, since we have not yet determined the mercury form or the binding sites of mercury in the tissues. The greatest part of the mercury is likely to be in its methy form (Fimreite et al., 1974; Osborn et al., 1979). We therefore compared our data with published results on methylmercury. Laboratory studies revealed that mercury levels of 3 to $13 \mu \mathrm{g} \mathrm{g}^{-1}$ in the liver lowered the hatchability by pheasants (Fimreite, 1971). In our study 29 birds out of $188(15 \%)$ had a contamination exceeding the $3 \mu \mathrm{g} \mathrm{g}^{-1}$ level, reflecting the possibility that $\mathrm{Hg}$ could have a negative effect on their reproduction. post of these birds were bird-eating raptors: sparrowhawk Accipite Thus and gosawk Accipiter gentilis, and fish-eating birds: cormorant, nisus and goshawk Accipiler gentilis, anted rebe Podiceps cristatus. On grey heron Ardea cinerea $17 \mathrm{gg}^{-1}$ was noted in the liver of hawks that died throun basis, some of the birds we analysed might have suffered from serious mercury poisoning ( $3 \%$ of the total), since their mercury levels were higher than $10 \mu \mathrm{g} \mathrm{g}^{-1}: 3$ great crested grebes, 2 grey herons, the cormorant, 1 goshawk and 1 tawny owl. Finally, a few birds showed an abnormally high liver to kidney ratio (see Figs 1 and 2), which could indicate an acute intoxication having eventually caused death: 3 grey herons, 1 great crested grebe, 6 barn owls and 1 sparrowhawk.

\section{ACKNOWLEDGEMENTS}

Technical assistance from M. Bogaert and statistical help from C. Lauwers are greatly appreciated. We are very grateful to D. Osborn for commenting on a first draft of this paper.

\section{REFERENCES}

Aberg, B., Ekman, L., Falk, R., Greitz, U., Persson, G. \& Snihs, J.-O. (1969). Metabolism of methyl mercury $\left({ }^{20} \mathrm{Hg}\right)$ compo

Bakir, F., Damluji, S. F., Amin-Zaki, L., Martadha, M., Khalidi, A., Al-Rawi, A. (1973). Methyl mercury poisoning in Iraq. Science, N.Y. 181, 230-41.

Bell, A. A., Haas, M. B. \& Murton, R. K. (1978). Mercury residues in carcases of kestrel, sparrowhawks and barn owls. Ann. Rep. Inst. terr. Ecol., 1977, $56-7$.

Blaton, V. (1973). Invloed van kwik op het biologisch midden. IWL Meeting on Mercury Problems, Brussels, November 1973, 95-102.

Cooke, A. S., Bell, A. A. \& Haas, M. B. (1982). Predatory birds, pesticides and pollution. Cambridge, Institute of Terrestrial Ecology.

Dehairs, F., Decad, G. \& Baeyens, W. (1982). Comparative study of different in miological samples. Analusis, 10, 373-6.

Fimreite, N (1971). Effects of dietary methyl mercury on ring-necked pheasants. Can. Wild. Serv., Occ. Pap., 9, 4-31.

Fimreite, N. (1972). Mercury contamination of aquatic birds in North-western Ontario. Human impact on Game Species, 479-89.

Fimreite, N. \& Karstad, L. (1971). Effects of dietary methyl mercury on redtailed hawks. J. Wildl. Mgmt., 35, 293-300.

Fimreite, N., Fyfe, R. W. \& Keith, J. A. (1970). Mercury contamination of Canadian prairie seed eaters and their avian predators. Can. Fld Nat., 84,

Fimreite, N., Holsworth, W. N., Keith, J. A., Pearce, P. A. \& Gruchy, I. M. contamination in Canada. Can. Fld Nat., 85, 211-19. 


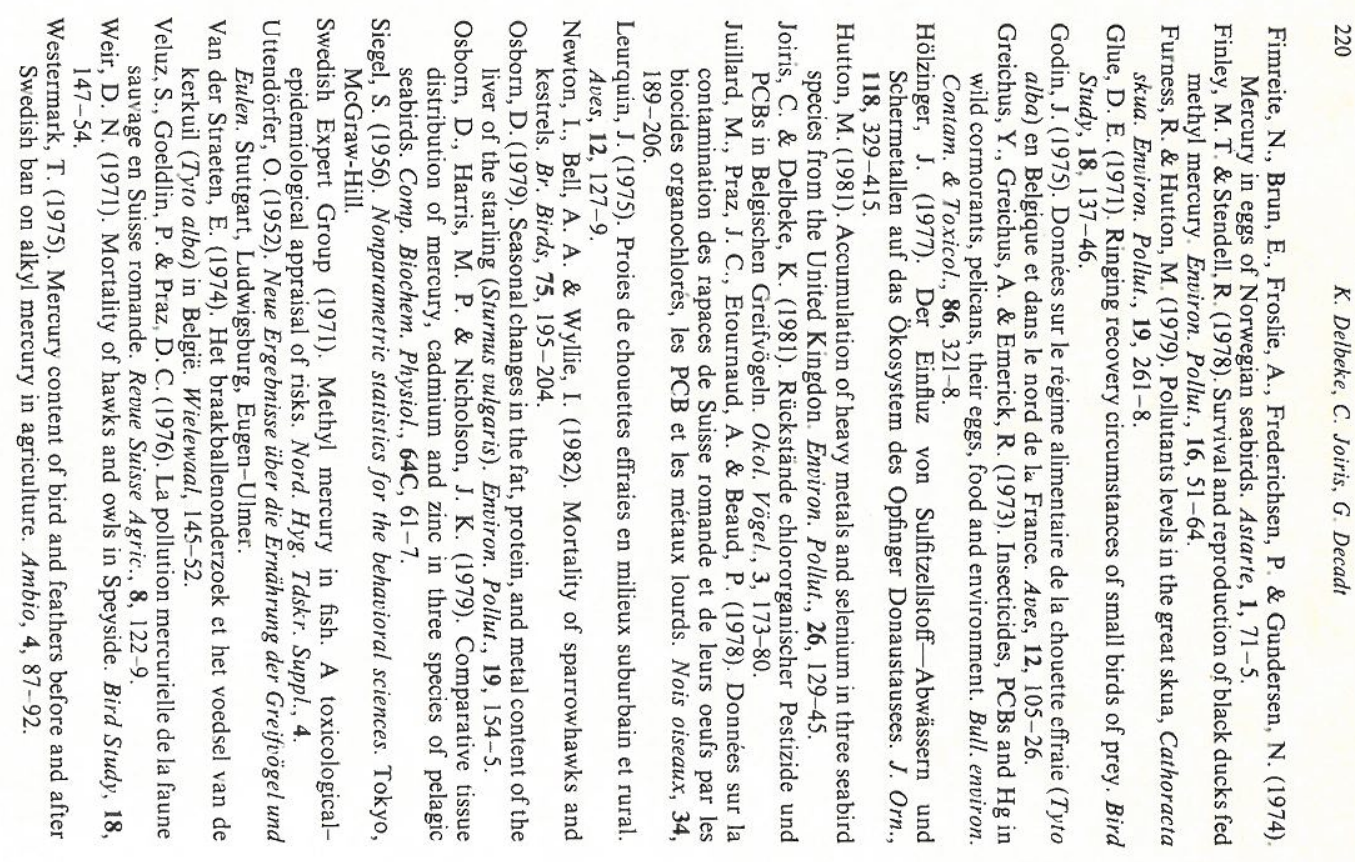

APPENDIX 1

The Mercury Contamination ( $\mu \mathrm{g} \mathrm{g}^{-1}$ wet weight) of the Muscle and Heart of Different Species of Birds ( $n$, number of samples; SD, standard deviation)

\begin{tabular}{|c|c|c|c|c|c|c|c|c|c|c|}
\hline \multirow[t]{3}{*}{ Species } & \multicolumn{10}{|c|}{ Mercury contamination } \\
\hline & \multicolumn{5}{|c|}{ Muscle } & \multicolumn{5}{|c|}{ Heart } \\
\hline & $n$ & Median & Mean & $S D$ & Min-Max & $n$ & Median & Mean & $S D$ & Min-Max \\
\hline $\begin{array}{l}\text { Cormorant } \\
\text { Phalacrocorax carbo }\end{array}$ & 1 & 1.41 & 1.41 & - & - & 1 & $1 \cdot 41$ & 1.41 & - & - \\
\hline $\begin{array}{l}\text { Kingfisher } \\
\text { Alcedo atthis }\end{array}$ & 4 & 0.77 & 0.73 & 0.38 & $0 \cdot 22-1 \cdot 13$ & 5 & $0 \cdot 18$ & 0.27 & 0.26 & $0 \cdot 12-0 \cdot 73$ \\
\hline $\begin{array}{l}\text { Honey buzzard } \\
\text { Pernis apivorus }\end{array}$ & 1 & $0 \cdot 15$ & $0 \cdot 15$ & - & - & 1 & 0.03 & 0.03 & - & - \\
\hline $\begin{array}{l}\text { Sparrowhawk } \\
\text { Accipiter nisus }\end{array}$ & 3 & $0 \cdot 71$ & $0 \cdot 81$ & $0 \cdot 19$ & $0.70-1.03$ & 2 & 0.96 & 0.96 & $0 \cdot 15$ & $0.85-1.07$ \\
\hline $\begin{array}{l}\text { Buzzard } \\
\text { Buteo buteo }\end{array}$ & 4 & $0 \cdot 15$ & $0 \cdot 20$ & $0 \cdot 20$ & $0.04-0.46$ & 2 & 0.16 & $0 \cdot 16$ & $0 \cdot 16$ & $0.05-0.28$ \\
\hline $\begin{array}{l}\text { Merlin } \\
\quad \text { Falco columbarius }\end{array}$ & 2 & $0 \cdot 17$ & 0.17 & 0.02 & $0.16-0.19$ & 1 & 0.24 & $0 \cdot 24$ & - & - \\
\hline $\begin{array}{l}\text { Kestrel } \\
\quad \text { Falco tinnunculus }\end{array}$ & 2 & 0.09 & 0.09 & 0.04 & $0.06-0.11$ & 2 & 0.09 & 0.09 & - & - \\
\hline $\begin{array}{l}\text { Barn owl } \\
\quad \text { Tyto alba }\end{array}$ & 5 & $0 \cdot 18$ & 0.18 & $0 \cdot 15$ & $0.01-0.41$ & 4 & 0.23 & $0 \cdot 20$ & $0 \cdot 16$ & $0.01-0.33$ \\
\hline $\begin{array}{l}\text { Long-eared owl } \\
\text { Asio otus }\end{array}$ & 1 & 0.01 & 0.01 & - & - & - & & & & \\
\hline
\end{tabular}

